Historic, Archive Document

Do not assume content reflects current scientific knowledge, policies, or practices. 



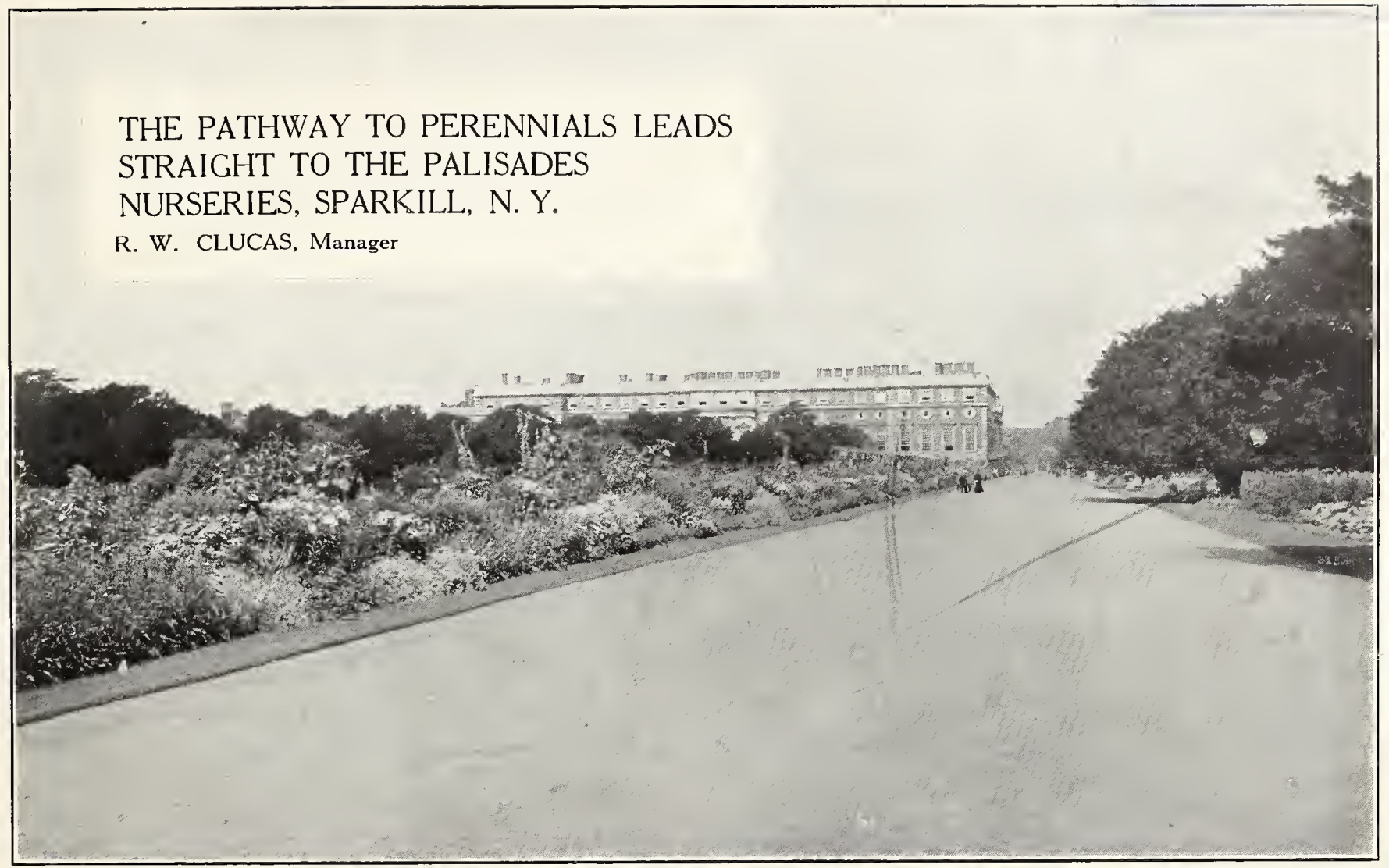
A Highway of Perennials leading to Hampton Court Palace, London. By planting this Fall, a similar effect can

\section{A HINT TO THE WISE-GARDENER}

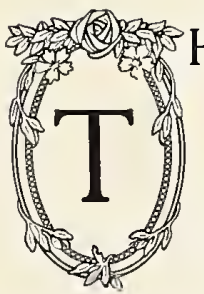

$\mathrm{HE}$ garden year is almost over; where yesterday there was a proud riot of Midsummer beauty, today there is the first faint whisper of coming Winter in the belated group of Autumn flowers. The garden speaks to us of the past rather than the present, and of the future rather than the past. For already we are planning the blooms of tomorrow instead of setting ourselves to mournful memories of faded blossoms. Now while the spirit of the garden is still holding us in its enchanted thrall is the time to make use of that enthusiasm; when our imaginations are working rapid fire with visionary beauties, when the faithful earth lies warm and ready to receive its green-leaved children, and when the plants themselves are settling duwn for the long Winter sleep. Now is the time to reach for the learned writings and mark well their sound advice on Fall planting. And now is the time to take to, heart the words of the wise men, and busy ourselves with preparations for next year's garden.

Fall planting has been slow in its appeal to the general garden lover, because it seemed foolish to begin planting when all the earth was preparing for a period of rest. Spring seemed ever so much more the seasonable time, when there was a stir in the growing world, and a stir in the human heart that urged him forth among green things. Then when young men's thoughts were turning to love, his were turning to the garden. He sat down with bulky catalogues, and in a great rush sent off for some plants to set in the earth. Impatiently he awaited their coming; hastily he set them in their appointed places and watched them slowly recover. 
Disappointedly he saw the days pass with never a bloom or scanty ones. Such is often the story with Spring planting. It is merely a question of education before Fall planting will be accepted as the reasonable, the most beneficial, and the most satisfactory in its results for the majority of plants.

Anyone interested in the structure of plants must realize what a severe shock and set-back it is for the system of the plant to be dug up by the roots from the earth, shipped for a distance without necessary moisture, and then transplanted in a new situation. After recovery from this experience, the plant must immediately stretch forth its roots in search of food, and begin the tremendous task of re-adjustment. It seems like heaping insult on injury to ask the poor plant to perform still another office for us, yet do we not expect it to grow apace and blossom forth in full glory the very same season? That is what Spring planting demands of the plant; an immediate recovery and establishment, followed by rapid growth and profuse bloom. But if the planting is done in the Fall of the year, there is a much better chance for the plant. It is not retarded just at the time when its growth is quickening, but it is dug up when the work for the year is drawing to a close and the plant system is preparing to make itself comfortable for the Winter. If the plant is transferred at this season, it can make this adjustment in the new surroundings before cold weather sets in, and thus be prepared with the first days of Spring to put all its energy into new growth. There is no question of the superiority of Fall planting in this respect. It does indeed gain the planter an entire season, as

$7^{*}$ the bloom the Summer after planting thus will be abundant.
Spring planting also has the disiadvantage of favoring later-blooming plants, for it is then too late for 5. 1 the early flowering varieties. To renounce all the joys of the first Spring beauties is a great blow to any well-ordered garden. Think of missing all the the jolly Hyacinth-because we have not used a little foresight and planned for their coming the previous Autumn. So it is with the early-blooming perennialsthe Moss Pinks like a sea of color; the deep blue shyness of the Violets; the dewy freshness of the yellow Primulas; the exquisite bells of the Lily of the Valley-that whole host of little strangers that too often

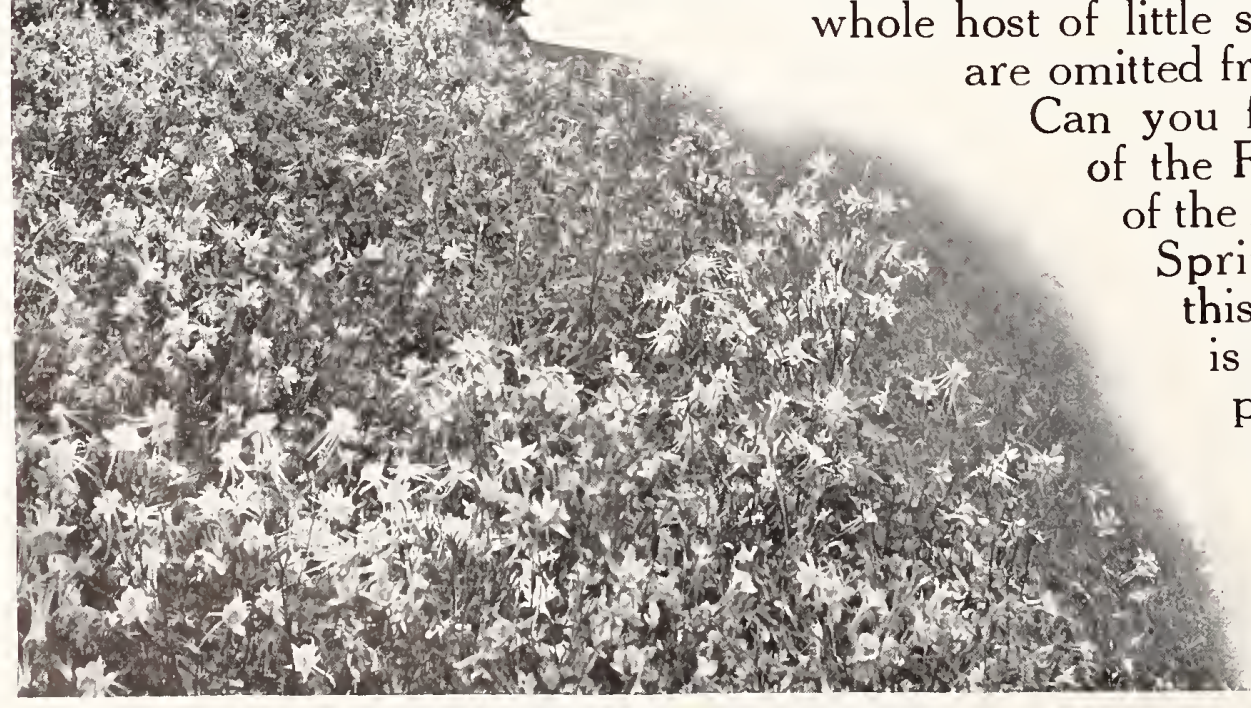

An effective planting of Aquilega and Foxglove omitted from the garden borders. Can you forego the golden bells the Forsythias, the blossoms of the Dogwood, and the other Spring-flowering shrubs this coming season? Now is the time to get busy and plan for their reception. Before the nippy days of Jack Frost comearound in earnest your future garden should be well on its way toward being planted out. 


\section{FALL SPECIAL OFFER OF PALISADES POPULAR PERENNIALS The Kind Our Grandmothers Grew}

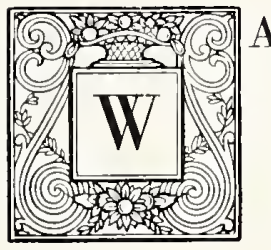

AS it ever brought to your notice how inexpensive it is to acquire a permanent flower garden that will last for generations?

After dreary Winter is past how fondly we look forward to seeing old associates of Spring and Summer time, who call anmually without the ceremony of digging or planting!

There are few things that call to mind more vividly pleasant recollections of our early life than the sight or odor of a simple flower, loved perhaps by some relative or friend; and what would be a more suitable remembrance than to plant such a one so that it may be called his or hers for time to come?

We give on the fourth and fifth pages of this circular a list of one hundred kinds with botanical and familiar names, with some of which you may have a fellow feeling, and if planted even in the least conspicuous corner or border this Fall they will make it tile most interestirig part of the garden next Spring and Summer.

WILHELM MILLER says in the Garden Magazine: "But now that the treasures of the Far East are lavished upon us, we have hardy plants suitable for practically every purpose the most exacting gardener can conceive. And wherever we have any special object to accomplish, we ought to try nine times to find a hardy plant that will do the work before falling back on a tender one. And this for two reasons: First, hardy plants harmonize better with our climate and environment than tropical plants; second, as a rule, they are cheaper to maintain. And, in the long run, those effects which grow naturally out of the soil, and out of true economy, will be recognized as the most artistic."

\section{TO ENCOURAGE FALL PLANTING WE ARE MAKING THIS SPECIAL OFFER}

You may select from one single plant to one thousand in any assortment (or we will make a selection for you) at the prices named below, and we deliver without further expense to your express or post-office (our option) strong flowering plants of varieties named on pages 4 and 5 of this circular. When a preference for specific varieties of the Perennials named is given we will try to comply.

PRICES at which we will deliver, express and postage paid, strong flowering plants of

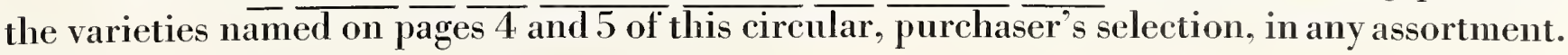

A single plant of any

variety named for - 15c. Any 25 plants for - \$2.25 Any 250 plants for $\$ 15.00$

Any 5 plants for - - 60c. Any 50 plants for - 4.00 Any 500 plants for 27.50

Any 10 plants for - $\$ 1.00$ Any 100 plants for - 7.50 Any 1000 plants for 50.00

When ordering refer to this Special Offer as $X X X$, which is void after November 30th 


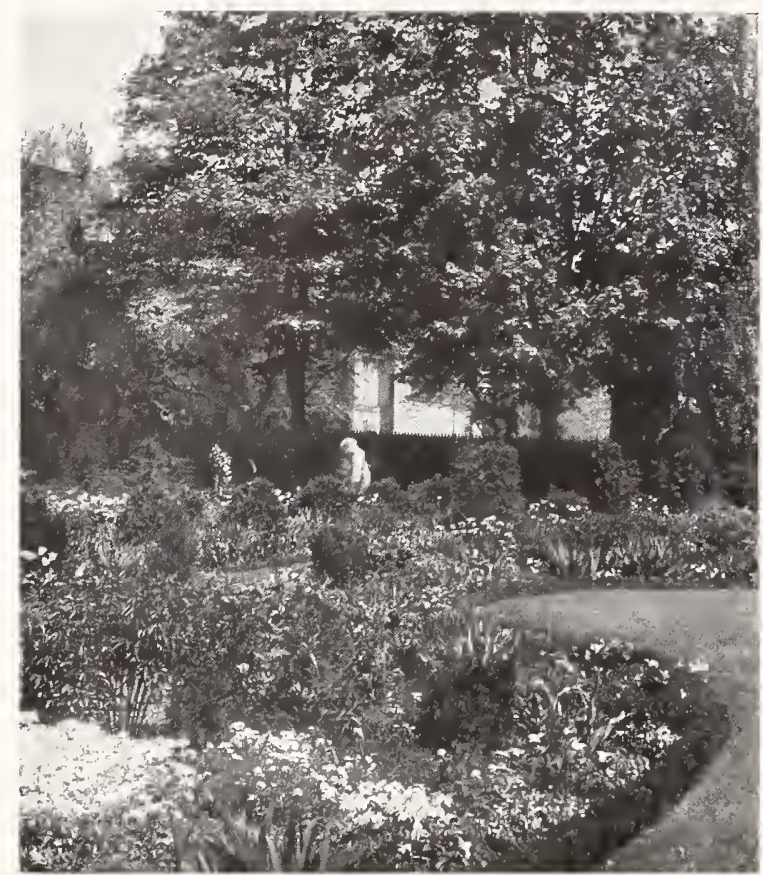

A delightful Perennial garden bordered with Boxwood

Achillea (Milfoil)

Aconitum (Monkshood)

Egopodium (Bishop's Weed)

Agrostemma (Rose Campion)

Alyssum (Madwort)

Anchusa (Sea Bugloss)

Anemone (Jap. Wind Flower)

Anthemis (Chamomile)

Aquilegia (Columbine)

Arabis (Rock Cress)

Armeria (Sea Pink)

Artemisia (Southernwood or Old Man)

Asclepias (Butterfly Flower)

Asters (Michaelmas Daisy)

Aster (Alpine Daisy)

Baptisia (False Indigo)

Bocconia (Plume Poppy)

Boltonia (False Chamomile)

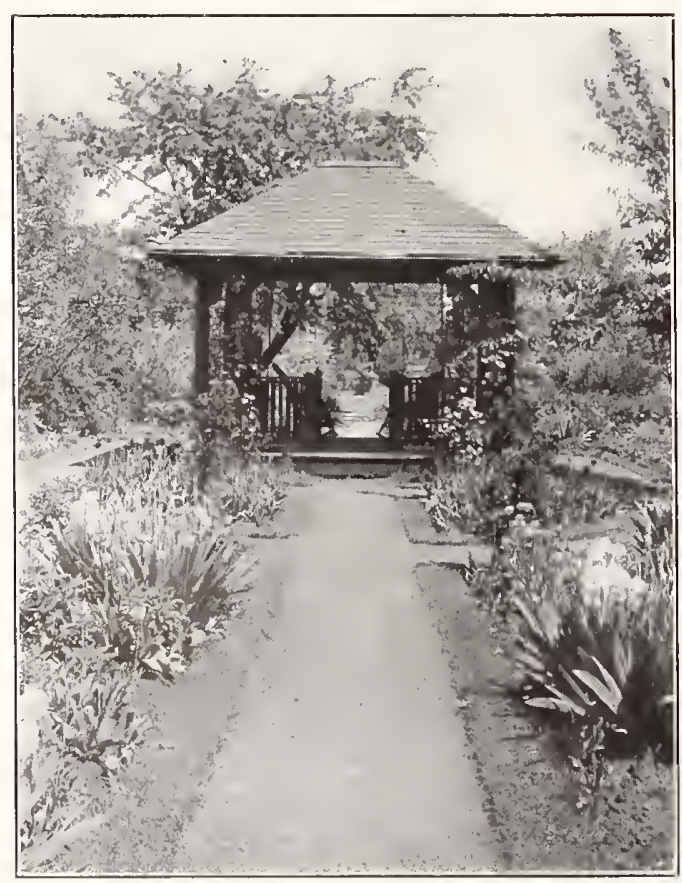

A charming approach to "My Ladies"

\section{PALISADES POPIIII OR OLD-FASHIONED FLOWER}

FOR PRICE

The illustrations on this page are intended to show what kning of Palisades Hard) ingin

Callirrhoe (Poppy Mallow)

Campanula (Canterbury Bells)

Centaurea (Hardy Corn Flower)

Ghelone (Shell Flower)

Ghrysanthemum (Giant Shasta Daisies)

Ghrysanthemum (Ilardy Japan)

Cimicifuga (Snakeroot)

Coreopsis (Tick Seed)

Costmary (Bible Leaf Plant)

Delphinium (Larkspur)

Dianthus (Hardy Carnation)

Digitalis (Fox Glove)

Eupatorium (Hardy Stevia)

Euphorbia (Flowering Spurge)

Funkia (Day-Lily)

Gaillardia (Aurora Flower)

Geranium (Hardy Geranium)

Geum (Red Buttercup)

Gypsophila (Baby's Breath)

Grasses (Ribbon Grass)

Helianthus (Hardy Sun Flowers)

Helenium (Sneezewort)

Heliopsis (Orange Sunflower)

Hemerocallis (Yellow Day-Lily)

Heuchera (Alum Root)

Hibiscus (Mallow)

Hollyhock, Double and Single

Iberis (Candytuft)

Iris (Fleur-de-lis)

Iris (Japanese)

Lathyrus (Everlasting Sweet Peas)

Liatris (Gay Feather)

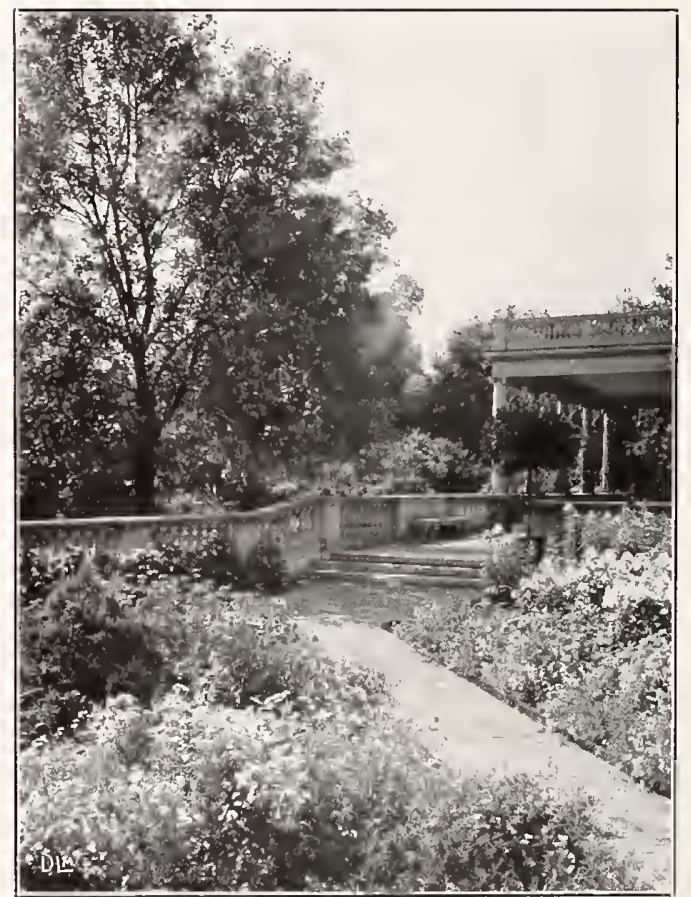

This picture shows a bright array of Perennials to be enjoyed from the verand

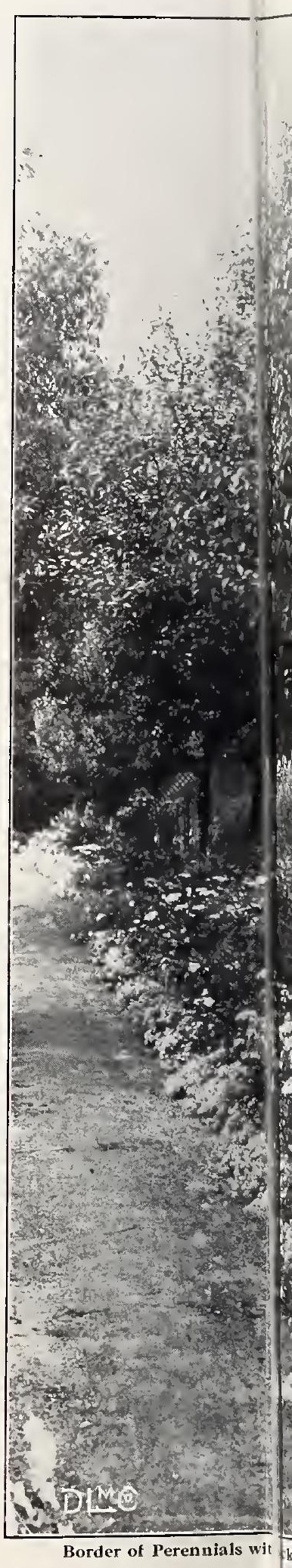




\section{IIAR PERENNIALS}

\section{IN ONE HUNDRED VARIETIES}

\section{E PAGE 3}

ing permanent effects can be produced by Fall planting nials and Shrubs

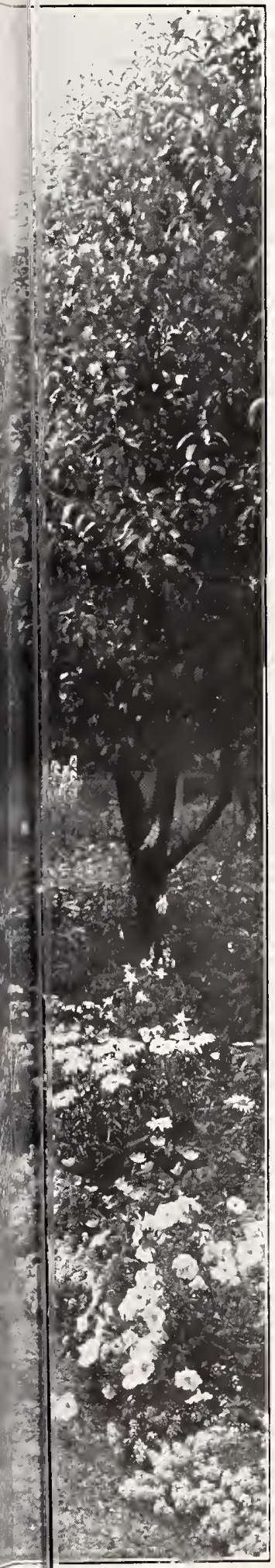

kground of Trees
Lilium (Hard́y Lilies)

Linum (Blue Flax)

Lobelia (Cardinal Flower)

Lupinus (Lupins)

Lychnis (Ragged Robin)

Lychnis Chalc. (Maltese Cross)

Lysimachia (Creeping Jenny)

Lythrum (Loosestrife)

Mertensia (Blue Bells)

Monarda (Horse Mint or Bee Balm)

Myosotis (Forget-Me-Not)

Nepeta (Variegated Ground Ivy)

(Enothera (Evening Primrose)

Pronies, Early Flowering

Papaver (Poppy, Oriental and Alpine)

Pardanthus (Blaekberry Lily)

Pentstemon (Beard Tongue)

Physostegia (Dragon Head)

Physalis (Chinese Lantern Plant)

Phlox Decussata (Hardy Garden)

Phlox Subulata (Moss Pink)

Platycodon (Jap. Bell Flower)

Plumbago (Leadwort)

Polemonium (Jacob's Ladder)

Polygonatum (Solomon's Seal)

Primula (English Primrose)

Primula (English Cowslip)

Pyrethrum (Persian Daisy)

Rudbeckia (Cone Flower)

Salvia azurea (Rocky Mt. Sage)

Santolina (Lavender Cotton)

Scabiosa (Blue Bonnet)

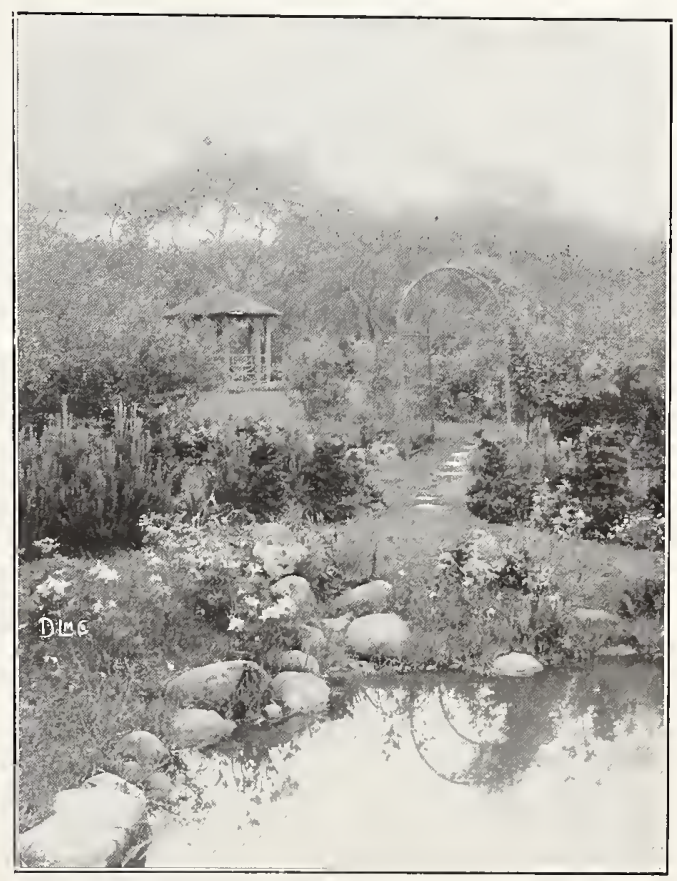

Many varieties of Perennials are suitable for planting on pool margins, making a very attractive showing

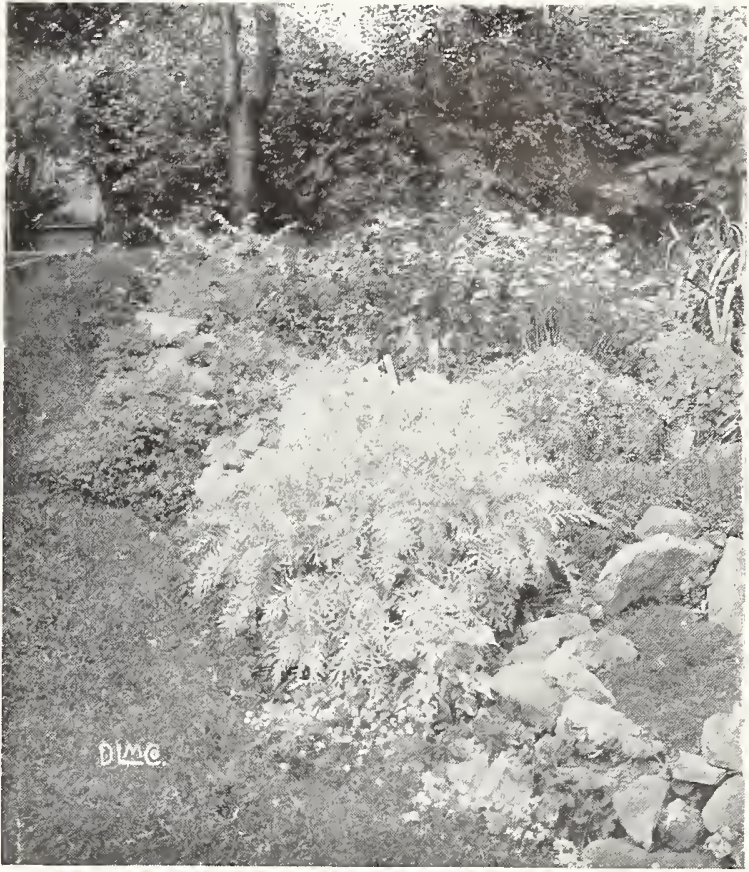

A fine Rockery in a cool and shady spot

Sedum (Stone Crop)

Sempervivum (House Leek)

Solidago (Goldenrod)

Spiræa (Meadow Sweet)

Stokesia (Stokes Aster)

Sweet William (Dianthus)

Thalictrum (Meadow Rue)

Thymus (Creeping Thyme)

Tradescantia (Spiderwort)

Tricyrtis (Toad Lily)

Trillium (Wood Lily or Wake Robin)

Tritoma (Red Hot Poker)

Valeriana (Garden Heliotrope)

Veronica (Speedwell)

Vinca (Creeping Myrtle)

Viola cornuta (Johnny Jumpups)

Viola (Sweet Scented Violets)

Yucca filamentosa (Adam's Needle)

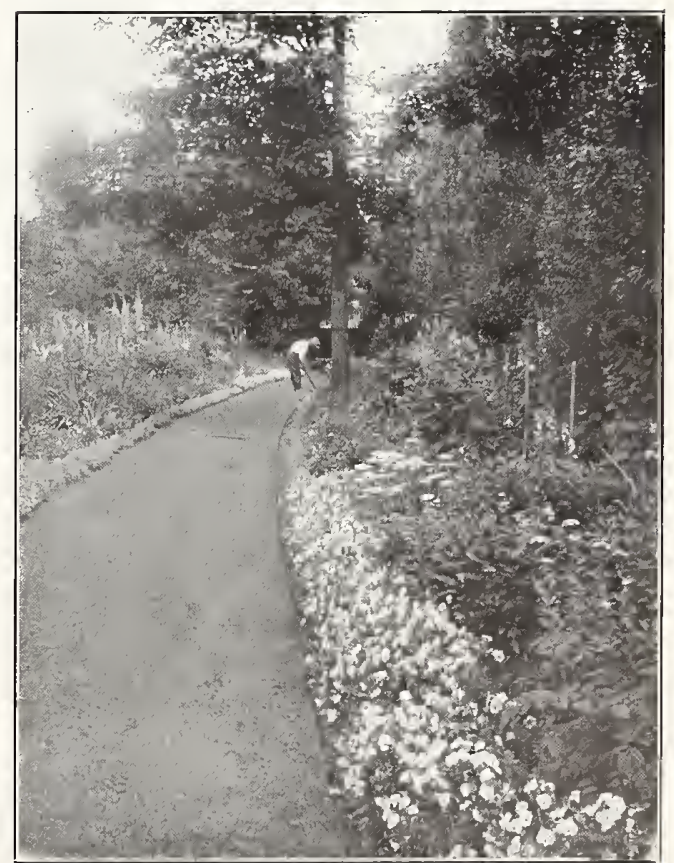

The garden path always looks well bordered with 



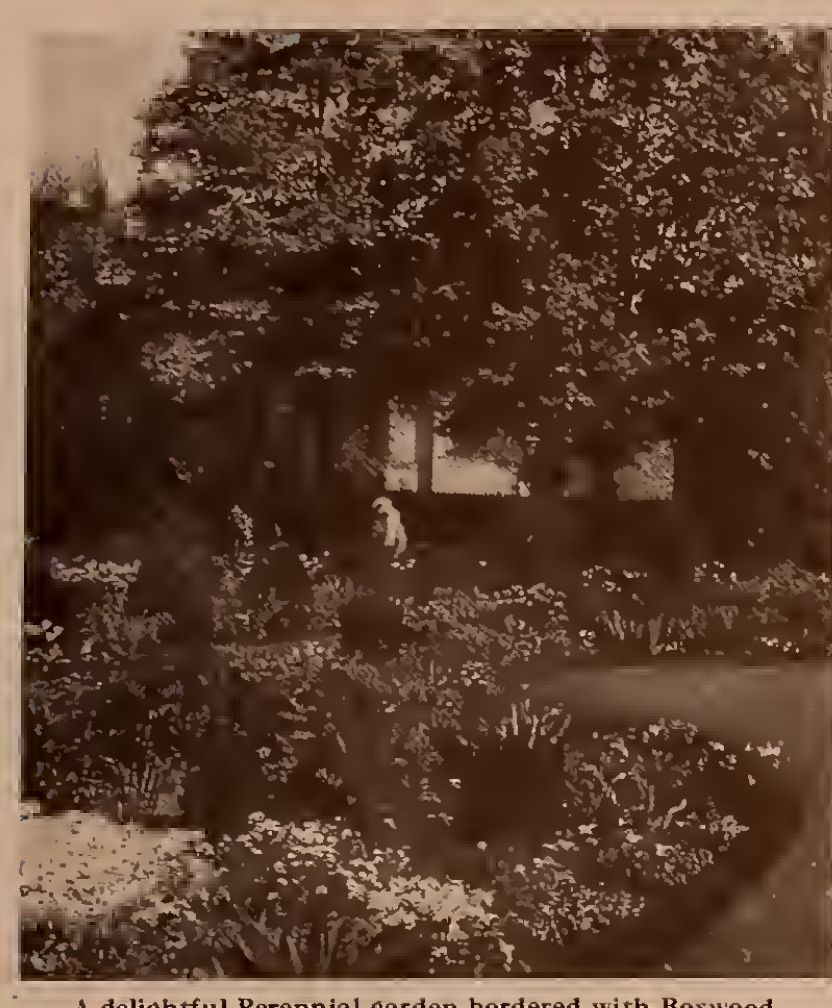

A delightrul Peren

Aconitum (Monkshood)

Agrostemma (Rose Campion)

Alyssum (Madwort)
Anchusa (Sea Bugloss)

Anchusa (Sea Bugloss)
Anemone (Jap. Wind Flower)

Anthomis (Chamomile)

Aquilegia (Columbine)

Arabis (Rock Cress)
Armeria (Sea Pink)

Armeria (Sea Pink)
Artemisia (Southernwood or Old Man)

Asclepias (Butterfly Flower)

Asters (Michaelmas Daisy)

Aster (Alpine Daisy)
Baptisia (False Indigo)

Baptisia (False Indigo)
Bocconia (Plume Poppy)
Boltonia (False Chamomile)

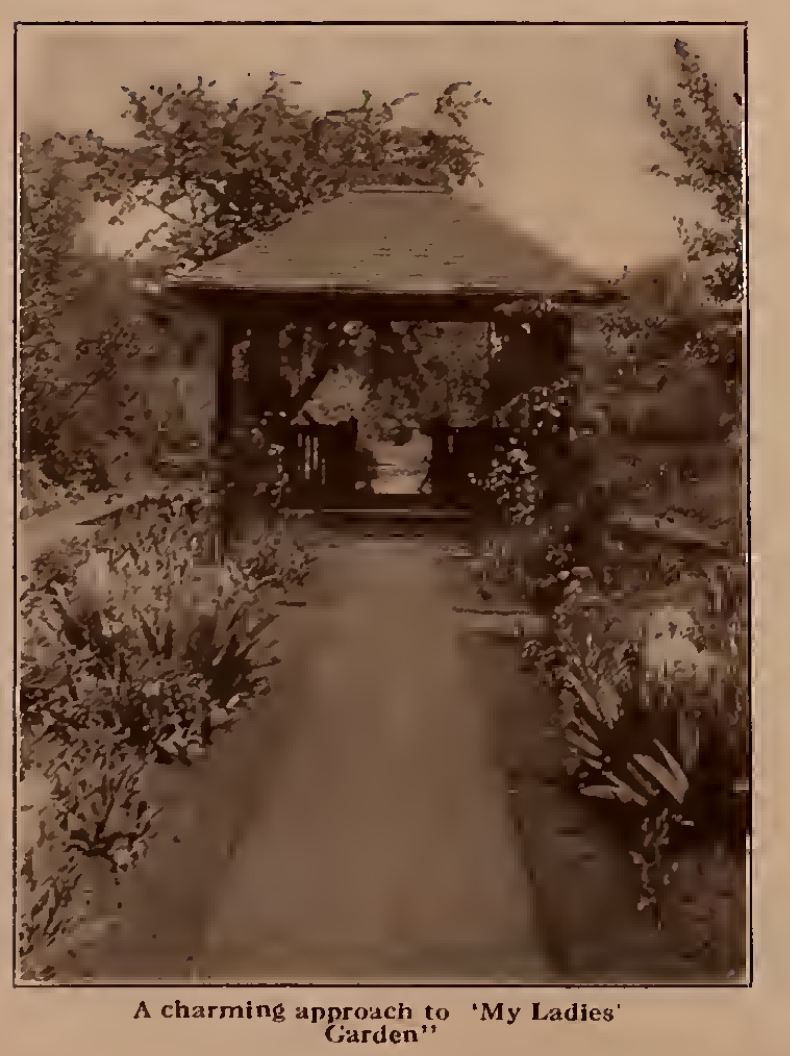

PALISADES POPULAR PERENNIALS

OR OLD-FASHIONED FLOWERS IN ONE HUNDRED VARIETIES FOR PRICESTSEE PAGE 3

Thic illustrations on this page are intended to show what cliarming permanent effects can be produced by Fall planting
of Palisades Hardy Perennials and Shrubs.

Callirrhoe (Poppy Mallow)
Campanula (Cantcrbury Bell Campanula (Cantcrbury Bells)

ant Shasta Daisies) Chrysanthemum (Hardy Japan) Cimicifuga (Snakeroot)
Coreopsis (Tick Seed)

Costmary (Bible Leaf Plant) Delphinium (Larkspur) Dianthus (Hardy Carnation)
Digitalis (Fox Glove) Digitalis (Fox Glove)
Eupatorium (Hardy Stevia) Euphorbia (Flowering Spurge) unkia (Day-Lily) Gaillardia (Aurora Flower) Geranium (Hardy Geranium) Gypsophila (Baby's Breatl) Helianthus (Hardy Sun Flowers) Helenium (Sneezewort) Hemerocallis (Yellow Day-Lily) Heuchera (Alum Root)

Hibiscus (Mallow)
Hollyhock, Double and Singlc Hollyhock, Double Iris (Fleur-de-lis)

Lathyrus (Everlasting Sweet Peas)
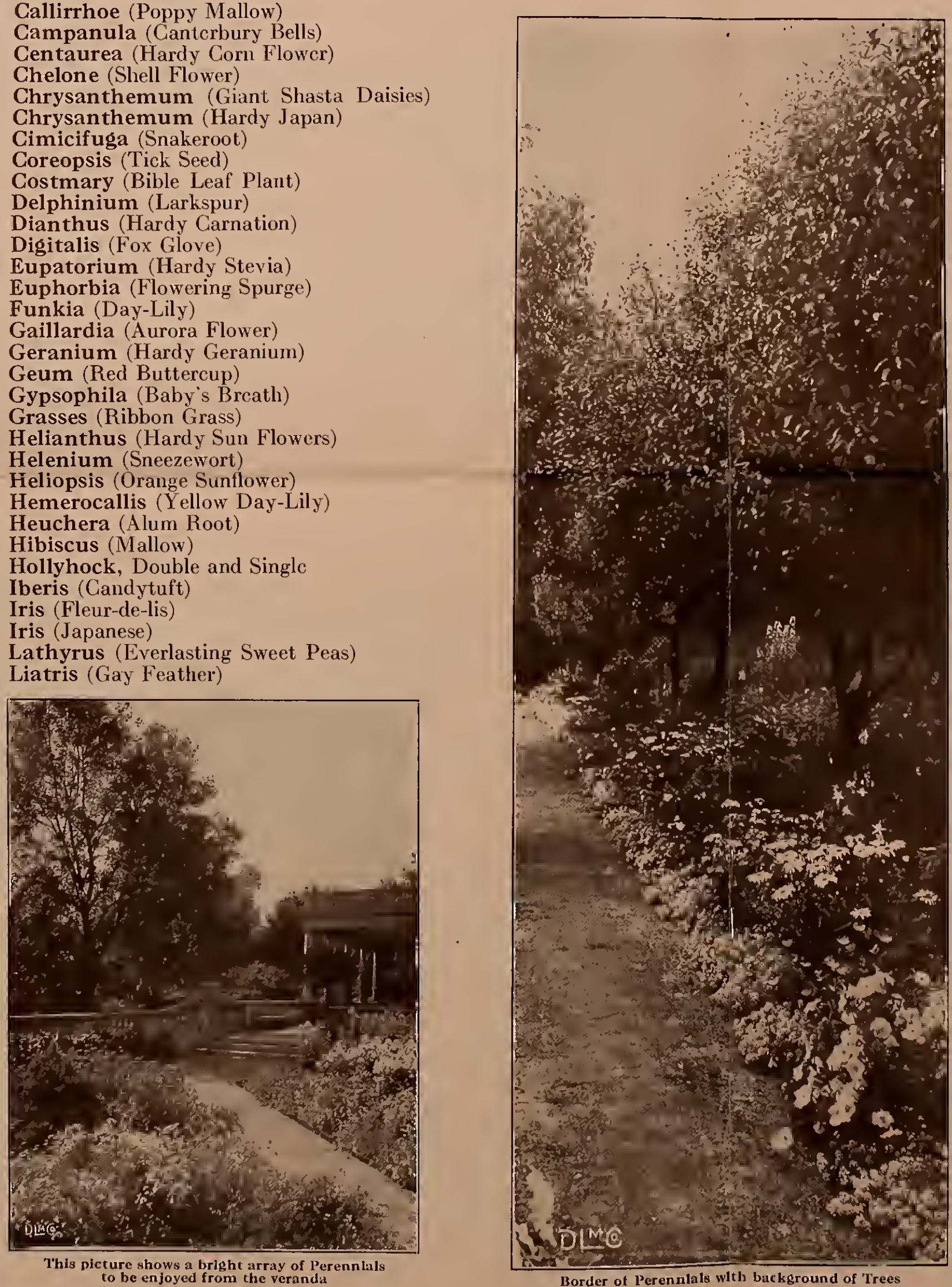

Lilium (Hardy Lilies)

Linum (Blue Flax)

Lobelia (Cardinal Flower)
Lupinus (Lupins)

Lypinus (Lupins) Lychnis Chalc. (Maltese Cross) Lysimachia (Creeping Jenny) Mythrum (Loosestrife) Monarda (Horse Mint or Bee Baln) Myosotis (Forget-Me-Not) Nepeta (Variegated Ground Ivy)
Enothera (Evening Primrose) G Enothera (Evening Primrose) Papaver (Poppy, Oriental and Alpine) Pardanthus (Blackberry Lily) Pentstemon (Beard Tongue)
Physostegia (Dragon Head) Physalis (Chinese Lantern Plant) Phlox Decussata (Hardy Garden) Phlox Subulata (Moss Pink)
Platycodon (Jap. Bell Flower) Platycodon (Jap. Bell Flower)
Plumbago (Leadwort) Polemonium (Jacob's Ladder) Polygonatum ('Solonon's Seal) Primula (English Primrose)
Primula (English Cowslip) Primula (English Cowslip)
Pyrethrum (Persian Daisy) Rudbeckia (Cone Flower) Salvia azurea (Rocky Mt. Sage) Santolina (Lavender Cotton)

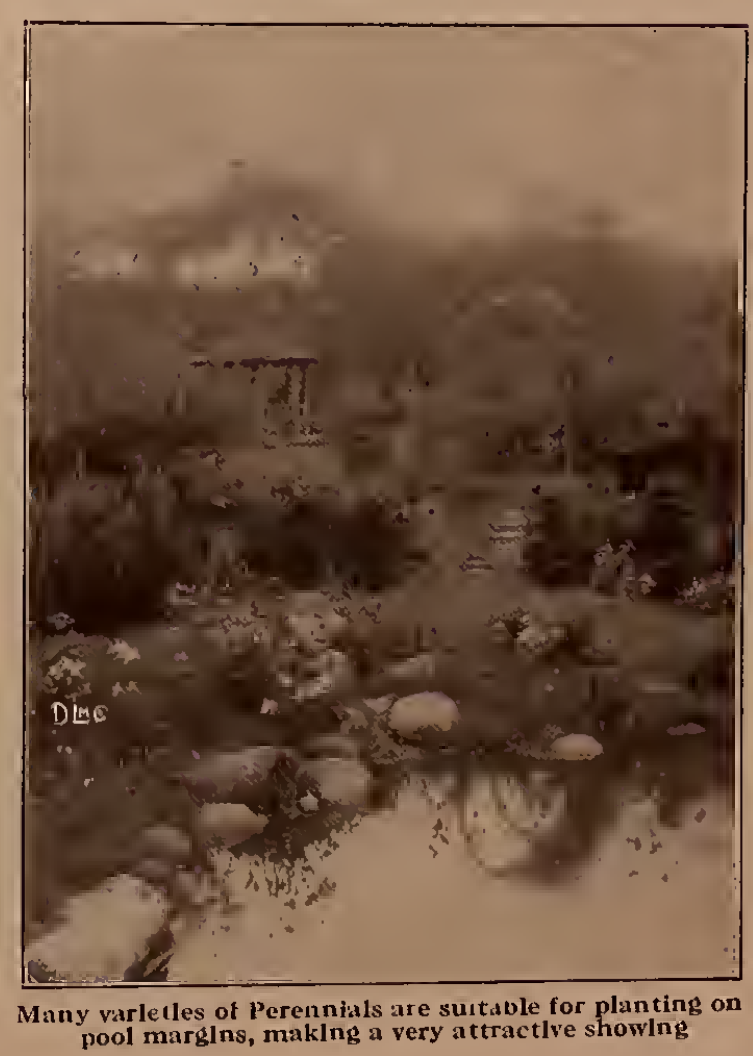

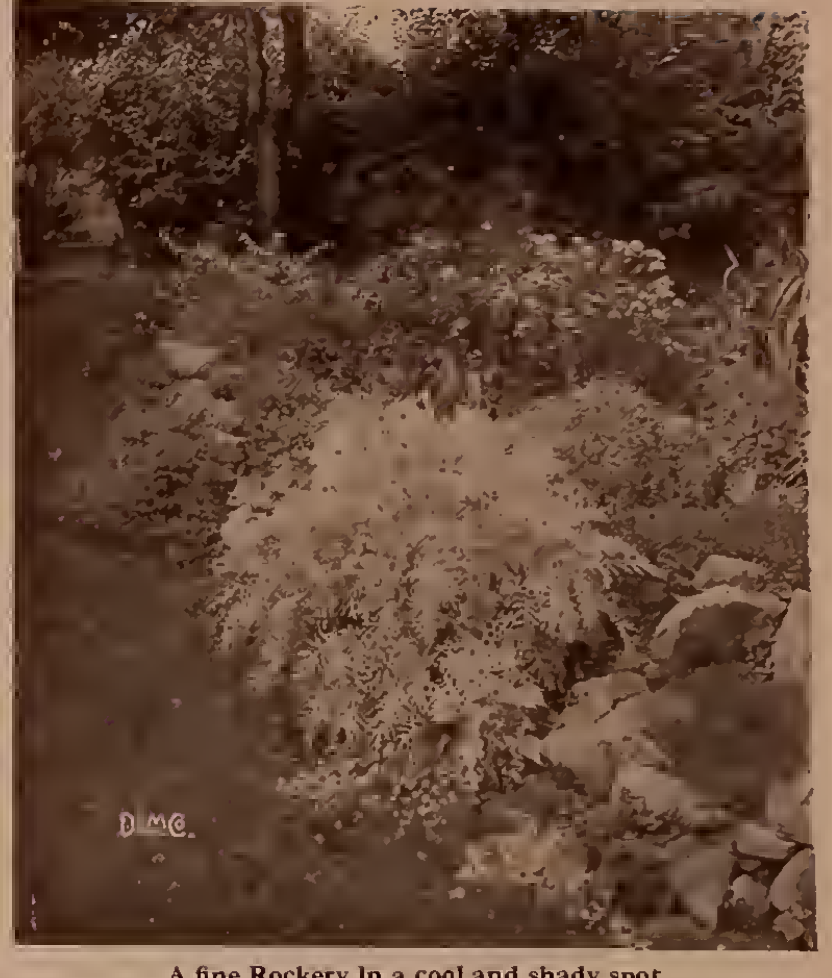
Sedum (Stone Crop)
Sempervivum (House Leek) Solidago (Goldenrod)

Spiræa (Meadow Sweet) Stokesia (Stokes Aster) Sweet William (Dianthus) Thymus (Crecping Thyme) Tradescantia (Spiderwort) Tricyrtis (Toad Lily) (Wood Lily or Wake Robin) Valeriana (Garden Heliotrope) Veronica (Speedwell) Vinca (Creeping Myrtle)
Viola cornuta (Jolinny Jumpups) Viola cornuta (Jolinny Jumpups)
Viola (Sweet Scented Violets)

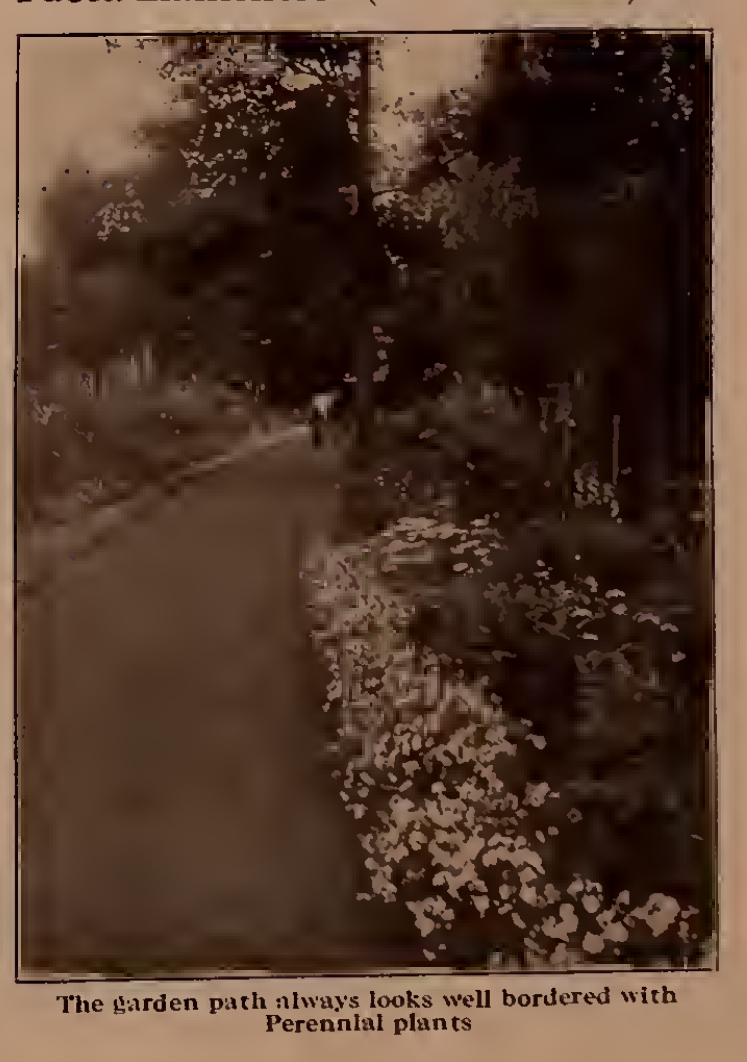




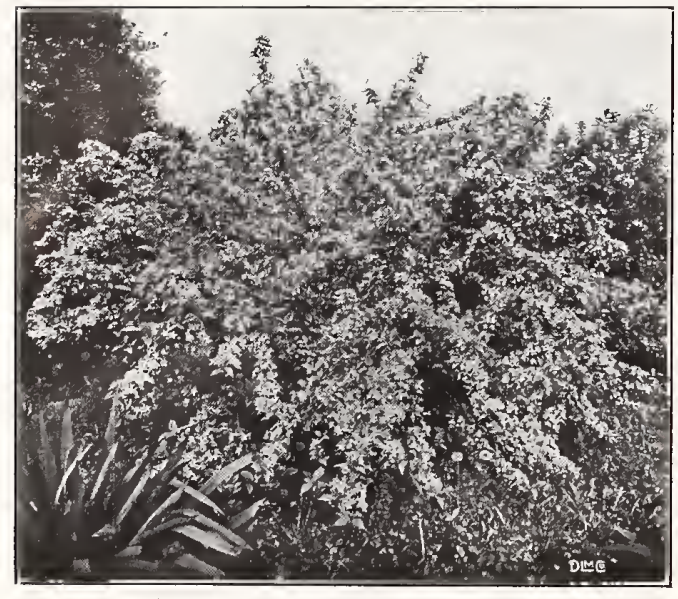

Weigela rosea variegata or Diervilla

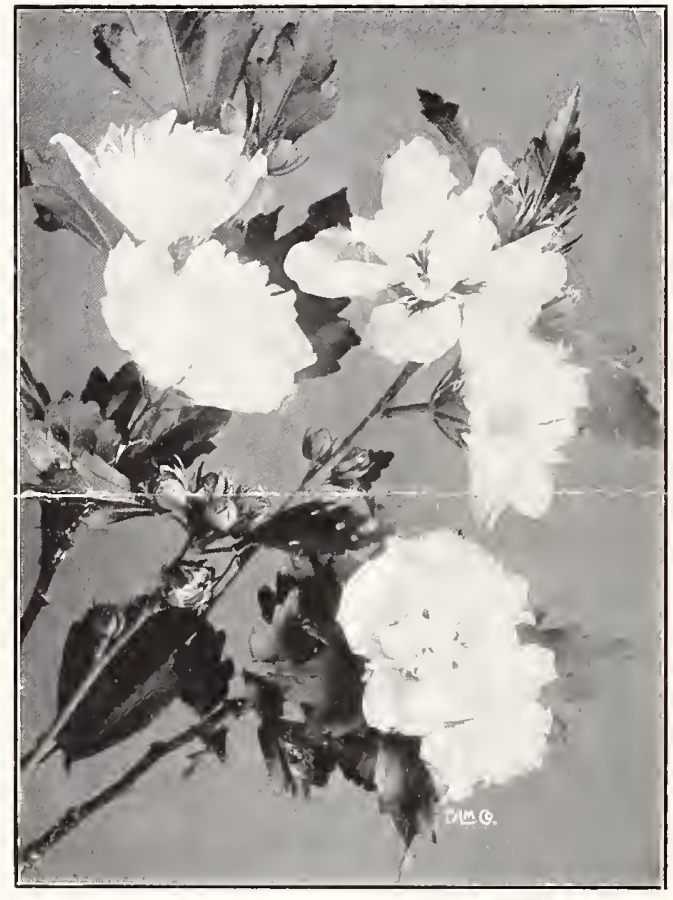

Althaea, Hibiscus or Rose of Sharon

\section{SPECIAL OFFER OF SHRUBS FOR THE LAWN}

Following is a list of twelve shrubs which are especially well adapted to planting on the home grounds around the house and which will prove a delight from early Spring until late Fall.

FORSYTHIA (Golden Bell), Showing masses of yellow flowers very early. GYDONIA (Japanese Qunce or Fire Bush). Blooming in May and best planted in Summer.

SYRINGA (Lilac). An old favorite in which several new forms are now offered. DIERVILLA (Weigela). Three colors, fiowering in June in almost any soil and pretty the season through.

SPIR AA Van Hout tei (Bridal IVreath). A wonderful shrub which looks in June almost as though weighted down with snow.

BUDDLEIA (Butterfly Bush, or Summer Lilac). A new shrub from China, which deserves a place in every garden, for its helotrope-colored flowers are produced from July until the coming of frost. Ver'y fragrant.

HYDRANGEA paniculata. Flowering in August and best grown as a lawn specimen, although it can be trimmed to suit any position.

ALTHAA, or Hibiscus (Rose of Sharon). A September-flowering shrub which has flowers resembling Hollybocks. Double and Single.

VIBURNUM (Snowball or High Bush Cranberry). Flowering in June, but with ornamental scarlet berries, which last well into the Winter.

SYMPHORICARPOS (Snowberry). Most valued for its large, white berries, which hang on the branches until long after snow flies.

PHILADELPHUS (Mock Orange, or Syringa). A well-known, hardy slurub. White, fragrant flowers. Blooms in June. Makes a large shrub.

DEUTZIA crenata. Double white flowers tinged with rose. Blooms the middle of June.

Prices at which we will furnish large-sized, well-branched shrubs for immediate effect of any of the above varieties: Each variety plainly labeled.

Plants, 2 to $3 \mathrm{ft}$. high, I5c. each, \$1.25 per doz., \$1 2.00 per Ioo, or a collection, one plant of each of the 12 varieties for $\$ 1.60$, or half a collection ( 6 plants) for $\$ 1.00$.

Extra strong plants, 3 to $4 \mathrm{ft}$. high, $25 \mathrm{c}$. each, $\$ 2.50$ per doz., $\$ 20.00$ per 100 , or a collection consisting of 12 plants, one of each of this size, for $\$ 2.75$, or half a collection ( 6 plants) for $\$ 1.50$.

These prices inchde boxing and packing, but not transportation charges. No less number than six of one variety sold at dozen rates or twenty-five at hundred rates. No restrictions as to number of collections ordered.

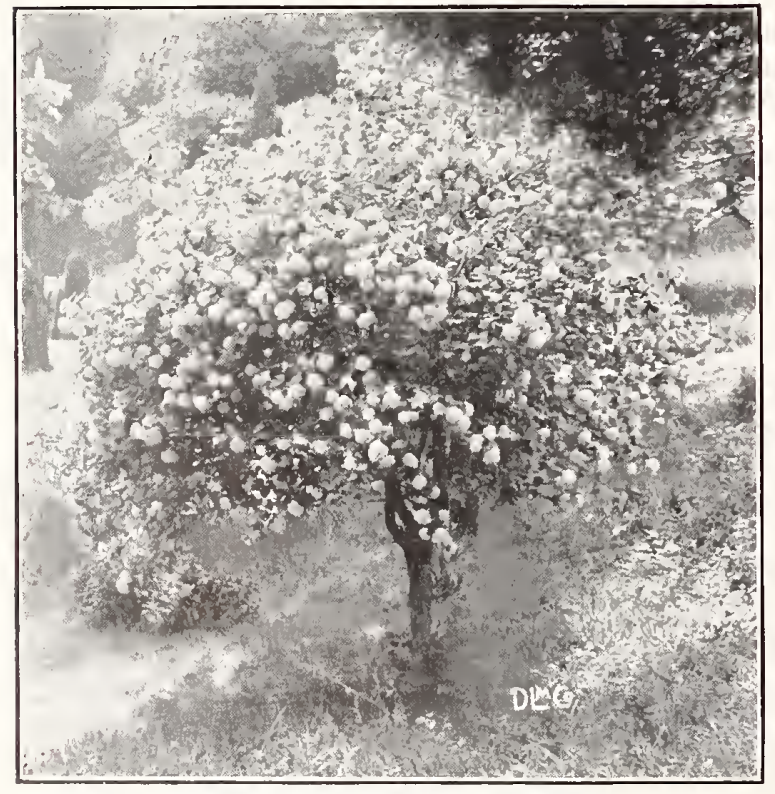

Viburnum opulus, Snowball Bush

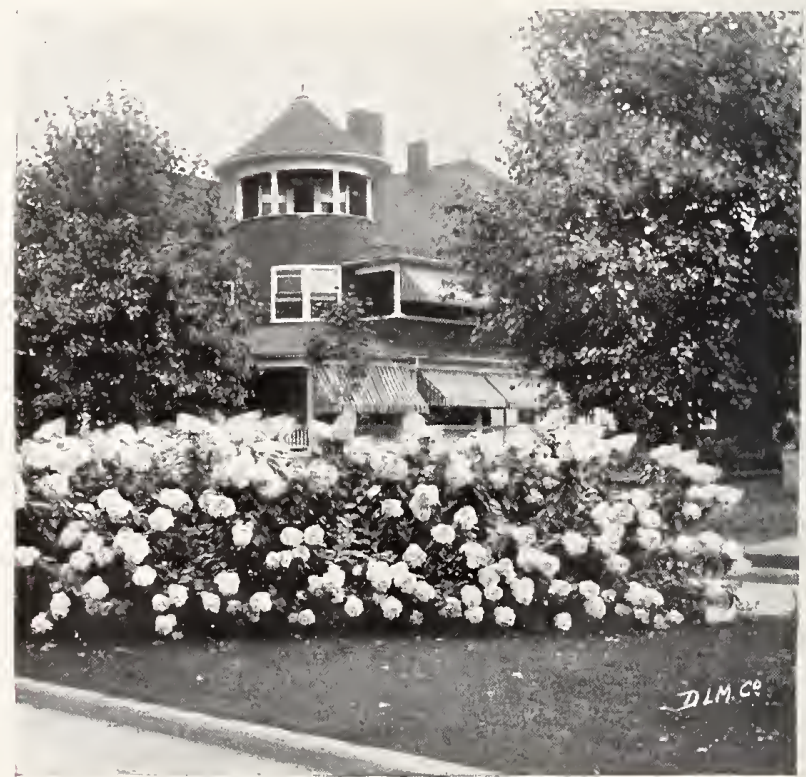

Planting of Ilydrangea Paniculata 


\section{AMERICA'S HARDY GARDEN}

TASHIONS in gardening have waxed and waned since the days of Colonial glory, but through the shifting changes of continental formality, there lias ever emerged pure and quaintly charming, that typical embodiment of America, the old-fashioned hardy garden. Like cosmopolitan Annerica, it has assimilated all the adaptable qualities of the best European styles into a conglomerate type, rather than created a distinctly new form for itself. It has gathered in its bosom that host of hardy pioneers who can withstand the struggles and hardships of our cold north winds and bleak mountain peaks, and who, undaunted, can brave the rugged virgin soils of a new country. Sturdy native blooms and foreign titled queens alike find place side by side in the shelter of its enfolding borders. Imperishable, they rise more vigorous and strong with each succeeding season, instead of weakly living out their little Summer and leaving an enpty garden in their wake next Spring. Each year sees the garden assume a fuller bloom, maturity that reveals the memories of its youthful past and hopes

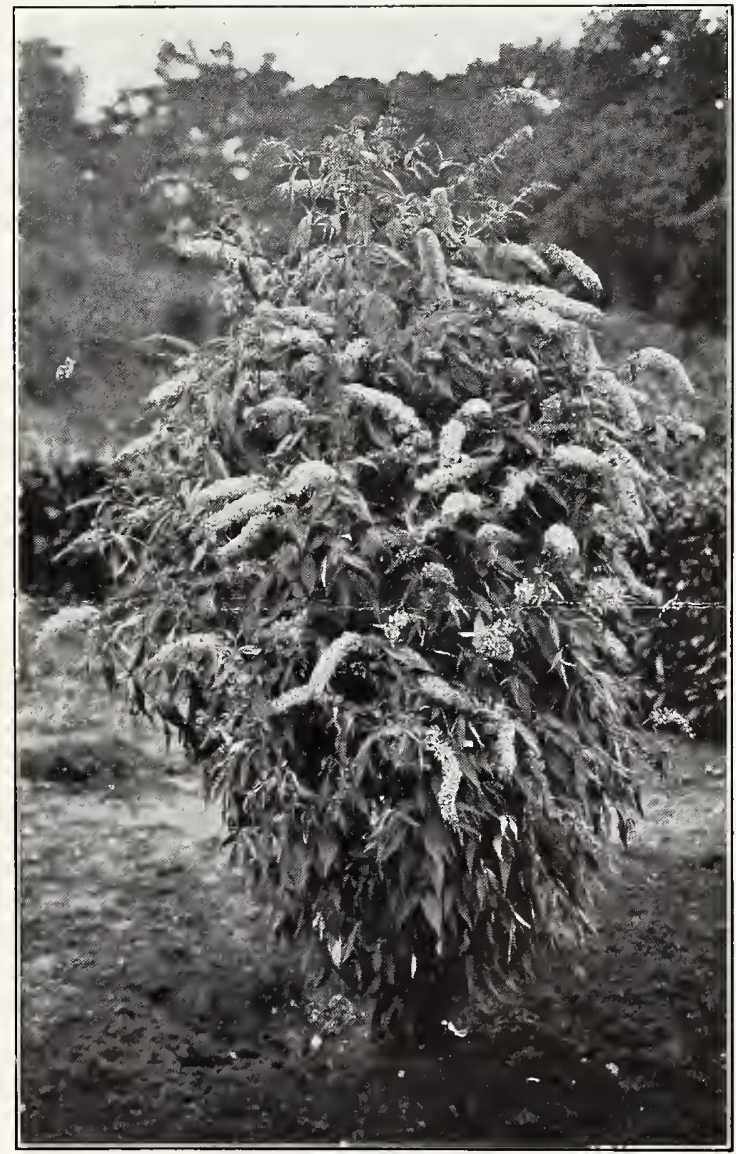

Buddleia, Summer Lilac or Butterfly Bush for its unknown future. From earliest Spring to latest Fall there is a constant procession of flowering color and beauty that makes of the garden enclosure a wonder spot on the earth. Once planted

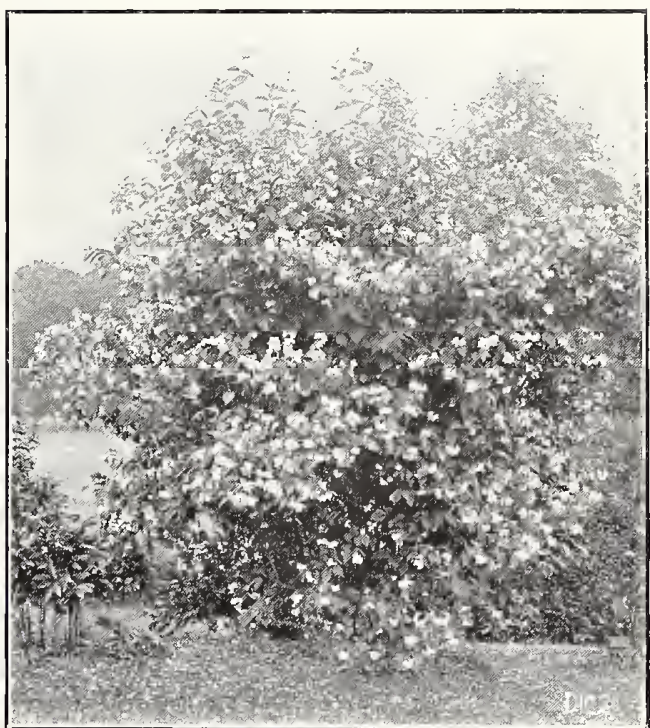

Philadelphus Syringa or Mock-Orange in their appointed places they firmly establish themselves and nced no further attention from human hands, fully repaying our thoughtfulness in placing them there by a riot of beautiful colors and forms. Such is the hardy perennial garden of old-fashioned favorites.

As we stroll through its informal by-paths, the reminiscent past comes floating before us, inseparably bound up with the sentiment of the flowers. One by one they troop through the imagination linked with the romance of former days. The tall spires of the jaunty Hollyhocks; the tinted cup and saucers of the Campanulas, the glorious full-blown petals of the Preones; and the delicious fragrance of the lowly Lavender. Even the names themselves are rich in that flower lore beloved of all true gardeners. The climbing Roses bend their profuse boucuets over the Bachelor Sweet William: the Phlox group of multitudinous wonderfully garbed sisters nod in friendly fashion to the elegant spikes of Larkspur, their neighbor; and when the frost is in the air the golden yellow Pompons of the Chrysanthemums are still smiling gayly at the sun amid the rayed and starry beauty of the Michaclmas Daisies.

The names and stories of the hardy garden members are laid before you in the preceding pages, and all the joys of foregathering a goodly company of congenial, companion blooms that will blend harmonious colors together and that will afford the fullest succession of bloom throughout the garden year are revealed in the list of "PALISADES POPULAR PERENNIALS," now at your service.

$\begin{array}{r}\text { Feb, 5th, 1915, } \\ \text { Salem, Mass } \\ \text { Palisades Nurseries, Ine, } \\ \text { Sparkill, N. Y. } \\ \text { Gentlemen I have } \\ \text { bought quite a little stuff } \\ \text { of you in the past, and } \\ \text { have always found it satis- } \\ \text { factory and the prices re- } \\ \text { markably reasonable } \\ \text { Yours very truly, H. L. C. } \\ \hline\end{array}$

\section{A PALISADE HARDY BORDER}

Our " Colonial," "Old-Fashioned," or " Grandmothers' Garden," with its single and double Hollyhocks, Larkspur, Foxglove, Phlox, Iris, P'nks, Columbine, Pxonias, Sunflowers, and a hundred other varieties arranged according to color, flowering season, size, etc.

A perfect picture in your garden to last for years will be the result if you allow us now to plan a scheme, whether of contrasts or of harmonies, to be carried out this Fall. Our "Artistic" Border 100 feet long by 4 feet wide, about 350 plants, costs $\$ 22.50$ only. Consider what is "saved" by this system and what is gained in true beauty.

\section{COST OF PLANS FOR MAKING A HARDY GARDEN OR BORDER AND HOW THEY MAY BE HAD FREE}

Beautiful landscape effects result only from a preconceived scheme of arrangement; hence the importance of a plan.

Plan for showing proper arrangements of single beds, or perennial borders $100 \times 4$ ft. $\$ 5.00$, FreE with orders for $\$ 2250$ and upwards worth of plants.

Plan for property containing $7500 \mathrm{sq}$. ft. or less $\ldots \ldots 10.00$, Free with orders for $\$ 100.00$ and upwards worth of plants.

Plan for property containing 7500 to 12,000 sq. ft orders for $\$ 150.00$ and upwards worth of plants.

Plan for property containing 12,000 to $20,000 \mathrm{sq}$. ft orders for $\$ 200.00$ and upwards worth of plants.

Plan for property containing over $20,000 \mathrm{sq}$. ft., special price.

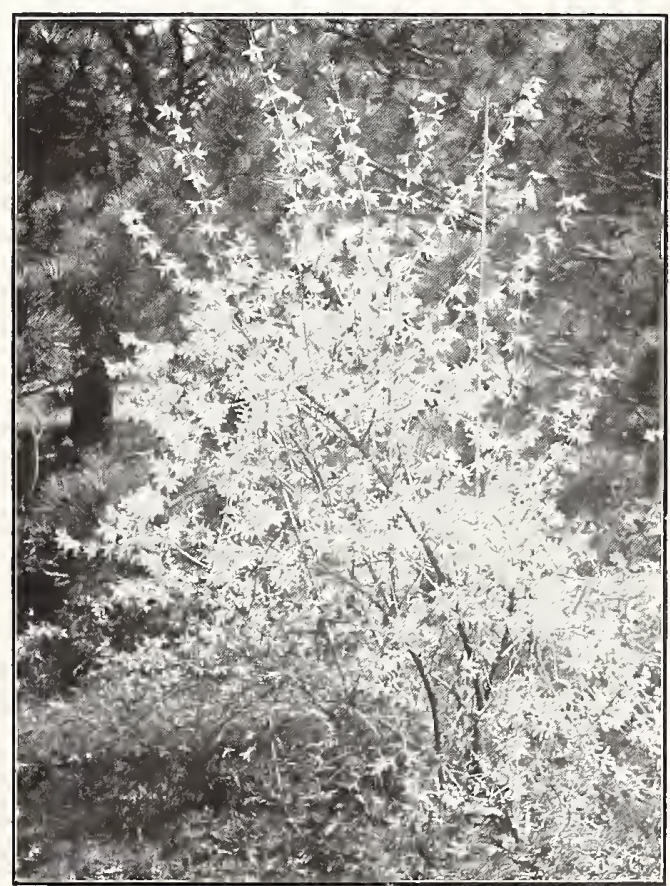

Forsythia, Golden Bell 


\section{THE PERENNIAL GARDEN}

The most beautifully

wrought beckding plant

with a well-designed peren-

nial garden, with its daily

surprises and new faces to

welcome us. One week it

next something different. It

resents an ever-changing

succession, commencing be-

fore the winter snows have

calls a halt in the Fall. This

is one reason why we should

grow more of this class of

that they fill the bill in every

size of a garden, from the

the cottage, to the broad acres of the millionaires.

The preparation of the

soil for a planting of peren-
nials should be most thor-

ough in every detail, if we

expect results that shall
excel. The work should be

of a permanent character.

The plan that I have generally adopted I find works well. Prepare the beds in the Fall by trenching or digging two spades deep. This breaks up the sub-soil. It should be dug and left in a rough condition, at the same time incorporating plenty of good rotten manure, or half-rotted leaves, or both, if the soil is very heavy. Thi makes the best medium for growing perennials. Give a good application of chareoal, peat moss, fibre or better still, plenty of good, tough sod. These materials will act as mechanieal agents to the soil, as effectiveness as a drouth resister, and a storehouse for plant food for

Deep cultivation is very essential as many of our bast perennial are deep-rooting; for example, the Leguminose, Malvace, Camdown to the cool reservoirs of moisture and air spaces during the parching months of July and August. The extra trouble of deep cultivation will be amply repaid in the extra quantity and quality of the flowers. In addition they will require less attention as to waing not only opens up the soil and allows freedoni of root action, trench also drains the soil in Winter, and renders it moist in Summer. The action on the pores of the soil is similar to the action of warm air in contaet with a cooler surface or body.

If the ground is of a vely sandy nature it is better to neutralize it by the action of cow manure (if procurable). Heavy elay loam with the sod left on is preferable. Wood ashes or lime applied at the time of preparation is als? good, as it has a binding effect on the soil, and being very "leachy," heavy mulching at all times is neessary for th (n) summer it prevents too rapid evaporation and pro-

I am rather in favor of nitrozenous manures for perennials, especially in the growing of the heavier varieties, although it is necessary to give a librak dressing of bone meal or granulated bone annually, as leguminous and wooty plants depend on the lime sait and phosphoric acid containcd therein. On the other hand, there are some plants that do not like lime, e. g., the Foxglove, but they are few in number.

There are two general methods in the planting of a perennial garden. The first is by arrangement of colors for certain sections o divisions. Of course in each case the aim is to have continuity of bloom for the cntire season, so arrange the heigh atc. This method might suit those who are partial to certain colors and shades and is easily accomplished.

Color planting is nore suitable for large gardens, where the eye rests on the whole, or greater part of the seheme. It also include the choice and use of two colors or combinations, such as pink and blue (light), cream and purple, golden yellow and deep blue, or orang and medium blue; or a gradual blending down from an intense color, using several intermediate shades. The yellow and orange shades always look well and if separated in good generous blocks, eannot help but be effective. Blocks of white flowers or green ornamenta to use strong colors in heavy masses, reds and scartets for example, that is if both meet the eye at the same time. The blue Delphiniums, white and pink y. Gypsophila and purple Delphinium form an æesthetic combination. Place Golden Coreopsis against heavy foliage and deep shadows. Plant Foxgloves among an underground of dwarfer material or among evergreens in groups. The composite flowers offer many delightful combinations. One cannot err in their use as the Examples include Heliopsis and Callimeris incisa, Stokesia and Shast Daisy. These can be used also with Golden Authemis. Rudbeckia purpurea and Rudbeekia fulgida or subtomentosa harmonize, and

ollections of Phlox show off to much advantage if separated as color, the searlets from the magentas and the pinks from the purples. Use the white forms between.
The second method of planting may appeal to those who want to form collections without regard to color arrangements. If so, use

planting of each genera or family in separate masses or in regular bays in conformity with the size and shape of that portion of the bed allotted pot to each group. Then plant evergreen shrubs at vantage also afford shelter in Winter from cutting winds and in Summer from hot sun for shade loving plants.

There are many genera which will thus make a continuous show of bloom by judicious placing and the use of the proportionate number. Take Veronica, for example. The first one blooms in the Spring, and so on till Fall, without a blank. Phlox are the same, starting with $P$, ovata, and followed by Arendsi, suffruticosa, and deeussata, giving an unending succession till October. Rudbeckia, Helianthus, Spiræa, Aconitum, Campanula, Helenium, Inula, Pentstemon, Lychnis, Lilium, Aquilegia, Gypsophila and many other families not including continuous bloomers, can be used in this way. If by chance there happens to be any blank spaces, any of the proous bloomers in the list fills the bil.

Propagation may be done in a number of ways. The most generally adopted method is by seeds. These should be sown early enough to form good, strong plants by October so as to enable them to stand the Winter. About June will usually suffice for many. I prefer sowing most everything in the Spring, as it takes a long time size than lose your stock through the Winter. Phlox are better sown in the Fall as soon as ripe. This is true also of a few other hard seeds, as many will not keep, such as Aquilegia, Myosotis and Primula. These must be sown as soon as possible. This method applies only to stocks which come true from seed or with which there is no regard or mixture. Any ehoice varieties, such as Phlox, Delphinium, Gaillardia etc., are better raised from cuttings or divisions.

Cuttings are made early in the Spring. A frame or greenhouse is a necessary adjunct for the purpose. By Wintering sueh stocks inside a cold house, they can be raised wholesale, and indeed many will bloom the first season. These euttings should be taken as short as possible on the side grow ths or when first starting to grow. Others can be multiplied from the roots, as having running fleshy roots they

Hom, Peony, Poppies, ete. much trouble, including the dwarfer eushion plants, such as Arabis, Campanula Carpathica Dianthus and others. All that it is necessary to do is to cover the plants with chean sand or sandy soil so as to form a mound, but not so thick as to bury the plant. Merely fill up the intervals between the leaves and stems. Some plants are better propagated by earthing up the stems in a similar way; for example, tree Pronies, and some others of a seni-shrubby nature.

The majority of herbaceous perennials are easily increased in smaller quantities by simple division of the roots. Those which deed, this method of dividing the roots should be carried out every few years, as the quality is better. If this is neglected, the clumps get hollow and woody in many cases, and are liable to run out. These include Pyrethrums, Delphiniums, Phlox, Pentstemon, Platycodon, Aquilegia, Aster and a host of others. A constant keeping up of the utmost vigor of your plants is essential both for quality and because they are then less liable to suffer from insect attacks.

It is not the intensity of our cold Winters that ruins many plants, but the dry, strong winds in early Spring, as well as the fact that water remains on the crowns and forms ice, thus suffocating them. To avoid much of this trouble, see that your border is well drained and this end do not clean the border off too clean and bare in the Fall; in fact, no more than is necessary. The more material that is left on in the way of a rough coating of leaves, ete. the more snow is liable to find a lodgment. In the case of evergreen plants, I find that pieces of hembeck or spruce branehes placed around them helps wonderfully. Do not cover these evergreen plants with a heavy mulch, as it will do more harm than good. They need air at all 